\title{
Complexity in Second Language Phonology Acquisition
}

\section{Complexidade na aquisição da fonologia de segunda língua}

Ronaldo Mangueira Lima Júnior*

Universidade de Brasília (UnB)

Brasília/DF - Brasil

\begin{abstract}
This paper aims at situating the representation and investigation of second language phonology acquisition in light of complexity theory. The first section presents a brief historical panorama of complexity and chaos theory on second language acquisition, followed by the possible phonological representations and analyses aligned with such perspective. Finally, the issue of second language phonology acquisition is revisited.
\end{abstract}

KEYWORDS: complexity; phonology; second language acquisition; dynamic systems theory.

RESUMO: Este artigo tem por objetivo situar a representação e a investigação da aquisição fonológica de segunda língua sob o prisma da complexidade. Parte-se de um breve panorama histórico sobre a teoria da complexidade e do caos na área da aquisição de segunda língua para então expor as possibilidades de representação e análise fonológica sob essa perspectiva. Finalmente, a questão da investigação da aquisição da fonologia de segunda língua é retomada.

PALAVRAS-CHAVE: complexidade; fonologia; aquisição de segunda língua; teoria de sistemas dinâmicos.

\section{Second Language Acquisition as a Complex Dynamic System}

Larsen-Freeman (1997) was a pioneer in applying the concepts of chaos and complexity theories to Second Language Acquisition (SLA). These theories arouse in exact sciences, with a focus on mathematics and physics, but have applications to virtually every science, including biology, meteorology, medicine, economy, oceanography, engineering, education and literature. Their applications in the cognitive sciences, especially in learning and

* ronaldo.limajr@gmail.com 
developmental psychology, appeared with proposals by Thelen and Smith (1994), Port and Van Gelder (1995), Port (2002), among others. In the field of linguistic development, there have been contributions from researchers such as Browman and Goldstein (e.g. 1987, 1988, 1989a, 1989b, 1990a, 1990b, 1992, 1993), Elman (1995), Cooper (1999), and Bassano and Van Geert (2007). In SLA research, since Larsen-Freeman's seminal work, several scholars have demonstrated interest in this research perspective, such as Kees De Bot, Wander Lowie, Marjolijn Verspoor, Marijn van Dijk, Lynne Cameron, Philip Herdina, Ulrike Jessner, Nick Ellis, and Adelaide Silva, ${ }^{1}$ to mention a few. The interest for the theory is also reflected in the organization of special round table events at the annual conferences of the American and the Canadian Association(s) of Applied Linguistics (AAAL and CAAL), and of the association of Teachers of English to Speakers of Other Languages (TESOL), all three held in 2006; as well as in the publication of the special issues of Applied Linguistics in 2006, coedited by Diane Larsen-Freeman and Nick Ellis; and of The Modern Language Journal in 2008, edited by Kees De Bot.

The work mentioned above helps demonstrate the impact that complexity theory has had on cognitive, linguistic and SLA research. It is a relatively new research perspective that is able to accommodate the manifold nature of language studies and should, hence, be taken into account by SLA researchers. Therefore, the main objective of this paper is to identify the key characteristics of complexity theory applied to SLA in order to show how this theory is able to approach the complex and dynamic nature of language, establishing itself as a sound theoretical foundation for research in second language (phonology) acquisition.

Some scholars refer to such theory as Dynamic Systems Theory (DST), others as Complex Adaptive Systems Theory, and still others as Non-linear Systems Theory, depending on the theoretical emphasis of each author, for these terms all transmit different characteristics of the systems under analysis. To simplify the reference, though, the term complex systems will be the one mainly used in this paper, which is also the one used by Larsen-Freeman (e.g. 1997, 2007; LARSEN-FREEMAN; CAMERON, 2008a, 2008b). Larsen-

\footnotetext{
${ }^{1}$ e.g. De Bot (2008), De Bot, Lowie and Verspoor (2007), Verspoor, Lowie and Dijk (2008), Verspoor, De Bot and Lowie (2011), Lowie (2010), Larsen-Freeman and Cameron (2008a; 2008b), Cameron (2003), Herdina and Jessner (2002), Jessner (2008), Ellis (1998, 2008a, 2008b), Ellis and Larsen-Freeman (2006, 2009), Silva (2008).
} 
Freeman identifies the SLA process as such a system, and, according to her, "complexity theory deals with the study of complex, dynamic, non-linear, selforganizing, open, emergent, sometimes chaotic, and adaptive systems" (LARSEN-FREEMAN; CAMERON, 2008a, p. 4), citation that encompasses the most important characteristics of this type of system.

The term complex refers to the fact that the system is composed of various elements or agents, but its behavior is beyond the sum of its individual agents' behaviors. The behavior of complex systems is not found in its individual components, but it emerges from the iterative and interconnected interactions of its components among themselves and with the environment, whose results are not predictable. Chaos in complexity theory is not lack of order, but rather unpredictability (DE BOT, 2008). Language satisfies this definition of complexity, for it is composed of subsystems, like morphology, phonology, syntax, pragmatics, etc., which are interdependent and which interact with one another and with the environment, in the social use of language, with changes in one subsystem provoking changes in all other subsystems and in the system as a whole.

Complex systems are dynamic because of their constant change in time. In complex systems, processes are more important than products, for their dynamic nature prevents them from reaching a final state. This characteristic of complex systems questions the possibility of SLA ever reaching a final state, that of the so-called ultimate attainment, or native-likeness. Rather, complex systems theory views SLA as an ongoing, dynamic and never-ending process. Even the term target language is questioned in a dynamic perspective, for complex systems simply do not have an end-state target.

The non-linear nature of complex systems is due to the fact that effects are disproportionate to causes. In linear systems, it is possible to calculate or foresee the effects or consequences of an action, which is not possible with non-linear systems. At the same time that some snow, for instance, may not cause anything when it falls on a mountain, a little pebble might cause an avalanche. This is also known as the "butterfly effect", coined by Lorenz (1972) when questioning if (or rather, suggesting that) the flap of a butterfly's wings in Brazil could cause a tornado in Texas. On the other hand, some great action may have very little - or even no effect at all. As De Bot, Lowie and Verspoor (2007, p. 8) put it: 
there is a non-linear relation between the size of an initial perturbation of a system and the effects it may have in the long run. Some minor changes may lead to huge effects, while major perturbations may be absorbed by the system without much change.

The non-linear relation between cause and effect, as well as complex systems' self-organization characteristic, is explained by Bak (1996) through the image of someone dropping sand on a surface. In the beginning, it is possible to drop several grains of sand, one onto the other, with the sand forming a cone-shaped pile. However, as more grains are added to the system, the pile becomes steeper and steeper, and the system reaches a critical point, at which one small grain may cause an avalanche, which, in turn, may also cause other avalanches, and these avalanches cannot be predicted in number or dimension. This is due to the fact that complex systems are sensitive to initial state, which is responsible for the non-linearity and non-predictability of the effects. Different initial states and their interactions with the components of the system can take the whole system through different paths. Complex systems in a critical state, such as that of the pile of sand, are characterized by high instability and unpredictable behavior. This illustrates the non-linear relation between the perturbation (grains of sand) and the results (avalanches).

An example of non-linearity in linguistics is the mapping of articulatory production and acoustic result, as proposed by Stevens (1972) in his Quantal Theory. To illustrate the basic concepts of Quantal Theory, Johnson (1997) uses the opening and closing of the glottis, which may vary from completely open, as when we pronounce $[\mathrm{h}]$, to completely closed, as in the production of the glottal stop [?]. If we pronounce [h] with the glottis wide open and start a linear and gradual movement of the vocal folds towards its closing, in a given moment there will be a quantal change that will make the vocal folds start to vibrate, resulting in a voiced sound. If we continue this linear movement towards closing the glottis, in a given moment another quantal change will occur, resulting in the glottal stop. Between these sounds, though, the phonetic-articulatory changes of glottal closing do not cause an acoustic result, as illustrated in FIG. 1. 


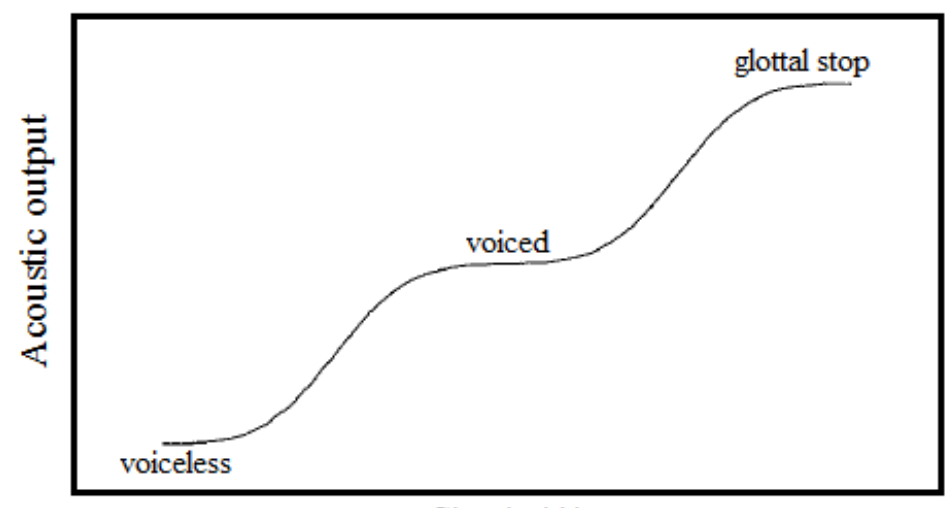

Glottal width

FIGURE 1 - Quantal Theory illustrated. Image used by Johnson (1997)

As Johnson (1997) puts it, a linear relation is like the volume knob on a radio, with each and every nuance of change on the knob causing the same change in the volume. A non-linear relation, on the other hand, is like the tuning knob on a radio, for at the same time that a small change on the knob might cause a great effect (getting one out of a station), great changes might also have no result at all (as when navigating through static radio frequencies).

The sensibility to initial state in SLA is evident in the various learner variables at play, such as age, motivation, exposure to L2, knowledge of another foreign language, level of literacy in the L1, socio-economic-cultural level, amount of feedback received, types of instruction received, etc., which highly influence the acquisition process, making L2 learners from the same class/course/ school develop non-linear learning routes and, thus, get to the end of their language course with diverse proficiency levels in the L2. The complexity of the L2 acquisition system is in the fact that none of the learners' characteristics can, in isolation, determine the (acquisition) system, because of the constant interaction of the many characteristics of each individual learner within him/ herself and with the environment. Furthermore, SLA is non-linear because the learning does not happen item by item, with the learner having to completely master one item before being able to move on to the next one. The acquisition curve has peaks and valleys, and progress has backslides. This way, the same learning action (or teaching action, in the teachers' viewpoint) may take the learners to completely different outcomes in the long run. Therefore, each intervention by the $\mathrm{L} 2$ teacher which aims at homogenizing the learning process may, in fact, take students through different developmental paths. 
The dynamic nature of the L2 learner language might also be seen in the definition of interlanguage (SELINKER, 1972), which places the learner proficiency in a continuum of constant development. Also, because of the interaction of the components of the system and because of self-organization, SLA emerges from the interaction of the learner with the language and with other speakers in social situations, making the language learning process an individual as well as a social endeavor.

The constant and dynamic changes of a complex system take place as it moves, or develops, towards attractors, which attempt to bring order to the system. Attractors are, by definition, temporary, non-fixed, and, thus, unpredictable, with different attractors demanding more or less energy to dislocate the system. De Bot, Lowie and Verspoor (1997) compare this movement with that of a small ball on a surface with some holes. As we tilt the surface, the ball might get out of one hole and stop on another, and the bigger and deeper the hole, the more we will have to tilt the surface to get the ball out of it, hence, the more energy will be needed to take the ball from one attractor state to another.

Fossilization, for instance, may be seen as an attractor. Therefore, even though it sometimes demands a lot of energy, it is always possible to get out of this attractor state. Fortunately, and contrary to what is implied by the jargon fossilization, attractor states are not an end in themselves; they are potentially temporary and transitory. In phonological acquisition, for example, it is possible that L2 learners store miscomprehended sounds in their systems and that these sounds become attractor states that demand a lot of energy for a movement of the system towards another attractor state that contains the appropriate sounds. Consequently, interlanguage development tends to be gradual and, at times, has abrupt changes, which show the (re)structuring attempts of the system through self-organization and/or attractors. Some attractors for L2 learners might reflect L1 influences or generalizations of L2 rules, but they cannot be predicted or explained by these characteristics, for attractors are the result of the constant changes and interactions of each learner's variables.

Each element of a complex system may have its own attractors, and its interactions with these attractors make global patterns emerge. The development of a complex system occurs from the interaction of its components and from self-organization, which takes us to the fractal characteristic of complex systems. A fractal is a geometric shape whose parts look like the whole. A tree or a broccoli is an example of a fractal, because as 
you look at the branches and boughs or the stem and sub-stems, these resemble the complete figure. This image reflects the iterative characteristic of complex systems, whose form emerges from iterative processes/cycles. "Through iterations of simple procedures that are applied over and over again with the output of the preceding iteration as the input of the next, complexity in language emerges" (DE BOT; LOWIE; VERSPOOR, 2007, p. 19). Language and SLA present fractal patterns as we analyze aspects of subsystems that are also present in the system as a whole.

Within all this complexity, because of the system's self-organization and its attractors, there are also moments of stability. In fact, SLA could not be a solely chaotic process. Throughout the acquisition process there are moments of more or less stability of the system, depending on the attractor states that the system has temporarily landed. For instance, in the acquisition of English as a first language, children first learn the past of irregular verbs because they are more frequent in the input. Therefore, it seems that the past formation system of such children is stable. However, when these children learn the rule to form the past of regular verbs, the system becomes unstable again, with the "-ed" suffix acting as an attractor, and children that already said "went" and "took" start saying "goed" and "taked". Nevertheless, since complex systems are able to self-organize, are sensitive to feedback, and because of the strength of other attractors, at a certain point this past formation subsystem will stabilize again, and both regular and irregular verbs will be produced appropriately. Concerning (L2) phonological acquisition, Flege's phonetic categories (e.g. 1995, 1999, 2007, 2010), Kuhl's magnets (1991, 1993), Bybee's (e.g. 2001, $2008,2010)$ or Cristófaro-Silva’s $(2003,2005)$ prototypes, as well as Steven's Quantal Theory plateau in the articulatory-acoustics mapping (1972), may be seen as attractor states.

Establishing languages and SLA as complex systems, according to Larsen-Freeman (1997), means to go beyond the dynamic concept that sees language as the process of aggregating static units. It also means to go beyond the dynamic concept applied to Schleicher's concept of language change and evolution. The dynamic concept associated with complex systems does not differentiate language use and language evolution, viewing these two processes as isomorphic. Language use changes the language itself, and its rules are modified by their actual use in real discourse, for "while rules can be used to describe such systems, the systems themselves are not the product of rules" (LARSEN-FREEMAN, 1997, p. 148). This view of grammar is in 
accordance with the concepts of functionalist grammars, such as Halliday's systemic functional grammar (1994), Bybee's usage-based phonology (e.g. 2001, 2002a, 2002b, 2008 and 2010), Pierrehumbert's probabilistic phonology (e.g. 1999, 2001a, 2001b, 2002 and 2003), Cristófaro-Silva's multirepresentational models (e.g. 2003, 2005, 2006a, 2006b, 2007; CRISTÓFARO-SILVA; GOMES, 2007), and Browman and Goldstein's articulatory phonology (e.g. 1987, 1988, 1989a, 1989b, 1990a, 1990b, 1992 and 1993), which was further developed to an acoustic-articulatory phonology by Albano (2001).

Regarding L1 and L2 acquisition, other approaches that, in different degrees, complement the view of the language acquisition process as a complex system are the emergentist approaches (e.g. MACWHINNEY, 1998, 1999, 2005, 2006; ELLIS, 1998, 2008b), connectionism (e.g. ELMAN, 1998; ELMAN et al., 1996; GASSER, 1990; ELLIS, 2003; ALVES; ZIMMER, 2005; THELEN; BATES, 2003), and the ecolinguistic approaches (e.g. LEATHER; VAN DAM, 2003; VAN LIER, 2004; COUTO, 2007), with the latter making use of a specific complex system, ecology, as the basis to explain how learners interact with their environment and context.

In an ecological perspective, the language learner is viewed as a complex system that is inserted in and that interacts with several other complex systems, which contain complex subsystems, and all of them interact among themselves and with the environment. The learner has his/her own cognitive ecosystem, and is inserted in a social ecosystem. De Bot, Lowie and Verspoor (2007) say that these ecosystems have resources, such as, in the case of the learner's ecosystem, his/her cognition, intelligence, motivation, exposure to the L2, aptitude, exposure to the L1, etc., and that these resources are compensatory, with low motivation being compensated by high exposure to the L2, for instance. Each resource also operates as a complex system, which uses the present state of the system as input to its development.

\section{Phonological Analysis under a Complex and Dynamic Perspective}

At the end of the 1980s and beginning of the 1990s, Browman and Goldstein (e.g. 1987, 1988, 1989a, 1989b, 1990a, 1990b, 1992, 1993) proposed a model to phonological representation and analysis based on complex dynamic systems, the Articulatory Phonology. In this approach, Browman and Goldstein attempted to ally phonetics and phonology for the common purpose of better understanding and describing speech in languages. 
They criticized studies on speech sciences up to that moment, because they tended to see speech as either a (bio)mechanical and physical activity (phonetics) or as a linguistic and cognitive structure (phonology). These two types of research, in their opinion, are in fact descriptions of two dimensions of one complex system and, hence, should be studied together, and this view brought both the physical/mechanical and the linguistic/cognitive aspects of speech to articulatory phonology.

Traditional phonological models have as a main point of investigation the fact that languages use a limited number of contrasts among words (macroscopic dimension) when compared to the number of articulatory possibilities (microscopic dimension), which ends up creating a gap between phonetic and phonological studies, with researchers of one area ignoring data from the other area. However, this decrease from the articulatory possibilities to what is actually used in a language can be interpreted as an example of the self-organization of a complex system, and this view rejects the separation between the physical and the cognitive. As was explained in the previous section, complex systems present patterns of global behavior that emerge from the local interactions of their components, with the global pattern itself serving as input for other local interactions. Therefore, it is plausible to interpret the macroscopic patterns (phonological) as an attractor state resulting from the self-organization of the interactions in the microscopic realm (phonetic) in the systematization of discrete representation (phonological, macroscopic).

In articulatory phonology, Browman and Goldstein (1992, p. 23) see the term phonology as "a set of relations among physically real events", which corresponds to traditional phonetics, "and patterns that these events enter into", which corresponds to traditional phonology. In a complex and dynamic systems methodology, the interaction among different, separate and, many times, dichotomic areas of studies, such as phonetics and phonology, is welcomed, as Larsen-Freeman (1997, p. 158) points out: "chaos/complexity theory encourages a blurring of boundaries in SLA - to see complementarity, and to practice inclusiveness where linguists have seen oppositions and exclusiveness."

The dialog between phonetics and phonology has been defended for a long time, by Keating (1989) and Pierrehumbert (1990), for instance, and has received more and more adepts, especially because of the complex systems perspective in linguistics, such as Leather (1999), Albano (2001), Silva (2003) and Cristófaro-Silva (2006b), to mention a few. In the introduction to the book Phonology in Context, edited by Martha Pennington, she sates that 
[...] we are at a point in linguistics where our divisions are interfering with progress and weakening our descriptive, explanatory, and predictive power. This is not the time to be reinforcing long-standing boundaries and carving up territories further, but rather, a time when we all need to be talking to each other (PENNINGTON, 2007, p. 3).

In articulatory phonology, the primitive unit is not the phoneme, but the articulatory gesture. The gesture is a dynamic unit of articulatory action, whose physical results can be seen in the movement of the articulators. It is "an abstract oscillation that specifies constriction in the vocal tract and induces the movements of the articulators" ${ }^{2}$ (ALBANO, 2001, p. 52). In line with the decrease of the barrier between phonetics and phonology, articulatory phonology has established the gesture not only as a unit of articulatory action, but also as the basic unit of contrast between distinct lexical items, that is, lexical items will contrast if they have different gestural compositions. In addition, the gesture has both an abstract and a concrete dimension, for besides being an abstract unit of representation, it can be observed and investigated in the movements of the articulators.

Browman and Goldstein have modeled the gesture through Saltzman's (1986) task dynamics, which is a motricity model that defines the movement not from individual movements of elements, but from the task to be accomplished, which, in this case, has been used to model the coordinated multiarticulatory actions of speech. One of the most important characteristics of task dynamics is that it is not the individual movements of the articulators that define speech dynamics, but rather the movement of the tract variables, under a complex systems perspective. Albano (2001, p. 43) sustains that the gesture "is materialized not in the effective movements of the articulators, but in invariant commands for the implementation of these movements in real time in the vocal tract". ${ }^{3}$

One difference between the phoneme and the gesture is that the former is a discrete, categorical unit, whereas the gesture has both a discrete dimension, when isolated and limited in time for investigation, and a gradient one, which is characterized by the gradient and overlapped movements of the articulators (BROWMAN; GOLDSTEIN, 1990b). The categorical nature of the phoneme

\footnotetext{
2 "uma oscilação abstrata que especifica constrição no trato vocal e induz os movimentos dos articuladores."

3 "se materializa não em movimentos efetivos dos articuladores, mas em comandos invariantes para a implementação desses movimentos em tempo real no trato vocal”.
} 
requires a lot of rules in order to explain certain phonological phenomena (SILVA, 2003), and these rules very often fail to explain the phenomena, as will be shown in the paragraphs to come, and as Chomsky and Halle themselves came to realize when they admitted that "the entire discussion of phonology in this book suffers from a fundamental theoretical inadequacy [...] the problem is that our approach to features, to rules, and to evaluation has been overly formal" (CHOMSKY; HALLE, 1968, p. 400 apud ALBANO, 2001, p. 38).

Besides this difference, phonemes are also: a) static; b) neutral in the articulatory-acoustics relation; and c) arranged in linear chunks. There has been a few post-generative phonological theories that attempted to challenge one or another of those characteristics, like the non-linear phonologies - e.g. Goldsmith's autosegmental phonology (1990) -, which questioned the linear arrangement of features. Nevertheless, articulatory phonology is able to challenge all those characteristics of the phoneme, for its primary unit, the gesture, has as its main characteristics: a) to be dynamic, once every gesture is a complex system in itself; b) not to be neutral in the articulatory-acoustics relation; and c) to overlap with other gestural units in the representation of discourse (BROWMAN; GOLDSTEIN, 1993).

The articulatory gesture is specified by means of a group of tract variables, which are five in the oral tract: lip aperture and protrusion, tongue tip constrict location and degree, tongue body constrict location and degree, velic aperture and glottal aperture. Tract variables are functional descriptions of the task and they distribute the movement associated with the gesture among the involved articulators. FIG. 2 shows the tract variables with their associated articulators, and FIG. 3 shows the tract variables in the vocal tract.

\begin{tabular}{|l|l|}
\hline \multicolumn{1}{|c|}{ Tract variable } & Articulators involved \\
\hline $\begin{array}{l}\text { 1) Lip protrusion } \\
\text { (2) Lip aperture }\end{array}$ & Upper \& lower lips, jaw \\
\hline $\begin{array}{l}\text { (3) Tongue tip constrict location } \\
\text { (4) Tongue tip constrict degree }\end{array}$ & Tongue tip, tongue body, jaw \\
\hline $\begin{array}{l}\text { (5) Tongue body constrict location } \\
\text { (6) Tongue body constrict degree }\end{array}$ & Tongue body, jaw \\
\hline (7) Velic aperture & Velum \\
\hline (8) Glottal aperture & Glottis \\
\hline
\end{tabular}

FIGURE 2 - Tract variables and their associated articulators 


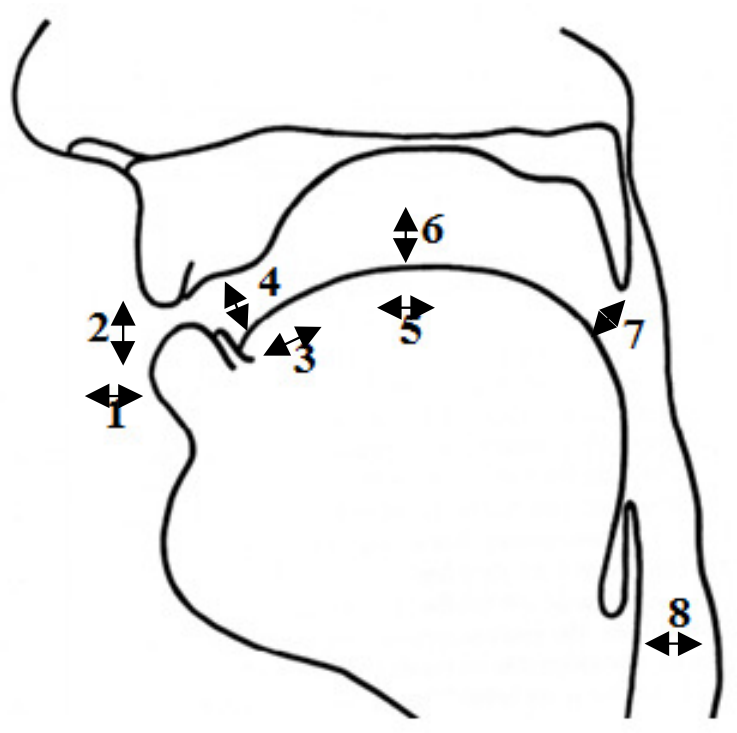

FIGURE 3 - Tract variables in the vocal tract

In FIG. 3, the tract variables that are inside the same cell are two dimensions of the same constriction and, thus, are considered related tract variables. This happens to the location and degree variables, as well as to the lip protrusion and aperture. Each variable also receives a gestural descriptor, or value, which can be as follows:

- In the variables "degree" and "aperture":

o Closed (stops);

o Critic (fricatives);

o Open, which, in "tongue body" and "glottal aperture", is further divided into:

- Narrow, which, in "tongue body", plus a descriptor of location, refers to a vowel; and, in "glottal aperture", refers to an unaspirated consonant;

- Medium, which, in "tongue body", plus a descriptor of location, refers to a vowel;

- Wide, which, in "tongue body", plus a descriptor of location, refers to a vowel; and, in "glottal aperture", refers to an aspirated consonant; 
- In "location" and "protrusion":

o In lips: protruse, labial, dental;

o In tongue tip: labial, dental, alveolar, post-alveolar, palatal;

o In tongue body: palatal, velar, uvular, pharyngeal.

These gestural descriptors, or values, are discrete and could perhaps resemble the "features" of (post-)generative phonologies; however, although descriptors may be binary, in the sense of being or not being present in the gesture, once present, descriptors display gradient and/or overlapping behaviors.

The description of a gesture includes a target for the tract variables, which is achieved by the coordinated action of articulators, which, in turn, is foreseen in a dynamic equation of a single oscillator system, such as that of the single pendulum, as explored in the task dynamics. The equilibrium position in the equation, which is the resting position of the pendulum, refers to the gesture achieving its target.

As has been mentioned, gestures also function as units of phonological contrast, for two distinct lexical items will contrast if they present distinct gestural compositions. This distinct composition may involve: a) the presence or absence of a gesture; b) a different tract variable controlled by the gesture; c) a different descriptor/value of a variable; or d) a different organization of the same gesture. Each of these contrasts is illustrated in the gestural scores of FIG. 4 and is further explained in the following paragraph. Gestural scores are used to illustrate the temporal relations in and among gestures. In a gestural score, each gesture is represented by a block, whose horizontal axis shows its duration in time, and whose relative height may represent its magnitude. Gestures that involve different tract variables are shown in different horizontal layers.
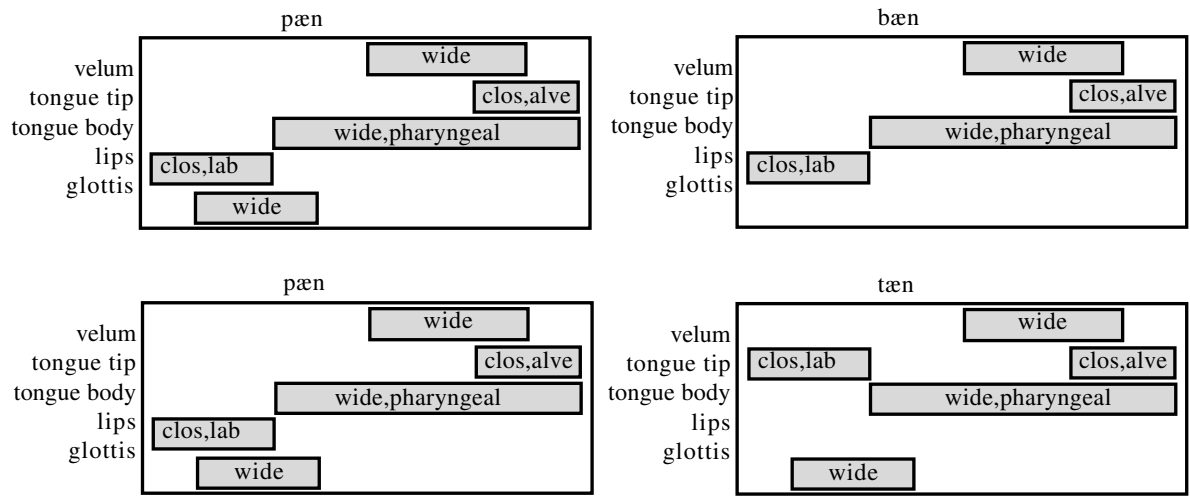

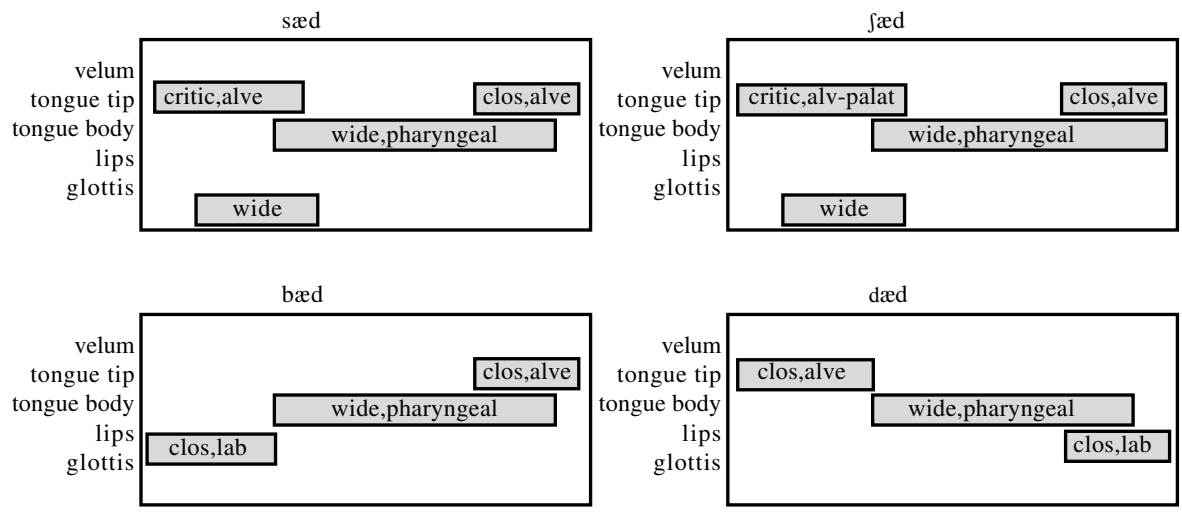

FIGURE 4-Gestural compositions that exemplify possible lexical contrasts (BROWMAN; GOLDSTEIN, 1993)

The first type of contrast, i.e. presence/absence of a gesture, is illustrated in "pan" versus "ban", for the only difference is that the former has a wide glottal aperture gesture while the latter does not. The same contrast type of contrast can be seen in "ban" versus "bad". They are distinguished by the absence of the velum lowering gesture in the latter, because the closure is not nasal, but solely alveolar. Likewise, if we remove the lips closure gesture in the beginning of "ban", we end up with "Ann". The second contrast is obtained when a different variable controls the gesture, as in "pan" and "tan", for the initial closing gesture is on the lips in "pan" and on the tongue tip (alveolar) in "tan". The next contrast lies in a different descriptor/value assigned to the same variable, as is the case between "sad" and "shad", whose critic value on tongue tip changes from alveolar to alveopalatal. Finally, the last type of contrast is found when comparing "bad" and "dab". In this case, both words have the exact same gestures, but coordinated differently.

The scores of FIG. 4 feature one of the most important characteristics of the articulatory gesture: the possibility of gesture overlap. Gestures may either not overlap and be arranged linearly, or they may overlap minimally, partially or completely. Gestural overlap allows for the study of gradient phenomena, as opposed to traditional phonologies, whose units of analysis are discrete and categorical. One example of a gradient phenomenon that no phonological model based on features can explain is the [S] that occurs in connected speech between words such as "miss you" [mI $\mathrm{mu}$. This [S] does not hold the same articulatory and acoustic characteristics of the [S] inside words 
like "mission". The connected speech [S] has an intermediary characteristic between $[s]$ and $\left[\int\right]^{4}$ (ALBANO, 1990). In feature-based phonological models, the explanation for such palatalization is given through the assimilation of features, a maneuver that is pointless in gestural phonologies because gestures have an extent in time predicted by the task dynamics and, as a result, the overlap of gestures produces audible articulatory and acoustics results.

Gestural overlap, aligned with the decrease of gestural magnitude, also substitutes feature erasing maneuvers typical of post-generative phonologies. Gestural overlap is able to account for phenomena that have traditionally been referred to as allophony, variation, assimilation, elision, etc. through general principles instead of categorical rules. Therefore, the possibility to overlap gestures means that a series of phonological phenomena take place automatically instead of having to be stipulated by specific rules, which makes articulatory phonology an implementational rather than a derivational model (SILVA, 2003).

Browman and Goldstein (1992) explain that one of the reasons for gestural overlap is related to the temporal difference between consonantal and vocalic gestures, since the former is shorter than the latter. This explanation is in line with the rhythmic unit proposed by Barbosa (e.g. 2006, 2008), the vowel-vowel (VV) unit, which goes from the onset of one vowel to the onset of the following vowel, including all consonants and glides in between. This proposal is based on studies that demonstrate the preservation of the duration of this unit as a means to maintain the rhythmic and intonational structures of speech. Therefore, the VV unit is more resistant to variation than the syllable. Within his dynamic model of Brazilian Portuguese rhythm, Barbosa (2006) shows how the VV unit may control gestural overlap.

One example of a phenomenon explained by articulatory phonology through overlap is what has been traditionally called allophonic variation. In the gestural scores of the four first words in FIG. 4, for instance, there is great overlap between the velic lowering gesture ("wide" in the variable "velic") and the gesture for the vowel ("wide and pharyngeal" in tongue body) because the beginning of the velic lowering gesture precedes the end of lip closure. This

\footnotetext{
${ }^{4}$ This also shows the limitation in the IPA, or any other transcription system, to accurately and appropriately represent phonetic-phonological articulatory-acoustic realities.
} 
results in a moment in time in which the nasal cavity is open and the vocal tract is in position to produce a vowel, or in other words, it results in a nasal vowel. The same does not happen with nasal consonants in the beginning of words because, in this case, the velic lowering gesture ends approximately at the same time that the lip closure gesture ends.

Traditionally, nasal vowels in English have been explained by a rule that transforms (intentional highlight) an oral vowel into a nasal one when preceded by a syllable-final nasal consonant, with the assimilation of the nasal feature. However, in gestural phonologies, English nasal vowels are simply the physical, regular and lawful result of how gestures are organized, discarding the need for one oral vowel to be transformed into another. The gesture for the vowel in "pan", i.e. wide and pharyngeal in tongue body, is exactly the same for the vowel in "pad", with the latter simply lacking the overlap of a velic lowering gesture at the end.

Gestural overlap can also explain phenomena of connected speech, such as (what has traditionally been called) assimilations, reductions, insertions, etc. For example, the insertion of the plosive $[t]$ in words like 'prince' [prInts] is the consequence of the anticipation of the velic closure in relation to the passage of the tongue body constriction from closed to critic, resulting in the audible effect [t] (ALBANO, 2001), as illustrated in FIG. 5.

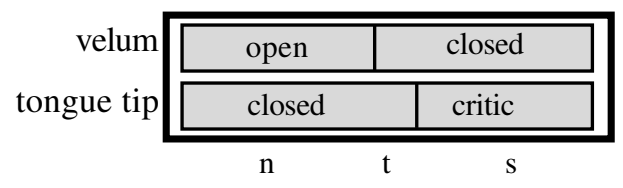

FIGURE 5 - insertion of $[\mathrm{t}]$ according to articulatory phonology (ALBANO, 2001)

Another phenomenon explained by the anticipation of a gesture is the reduction of $[\mathrm{t}]$ to $[\mathrm{r}]$ in some rhotic varieties of English, such as General American English. FIG. 6 exemplifies the flap in "get it" [gerit], where there is a shortening of the alveolar closure gesture on tongue tip added to a significant overlap of it with the vocalic gestures. According to Albano (2001, p. 59), "no static phonological model is able to explain phenomena like this one". 5

5 "nenhum modelo fonológico estático é capaz de dar conta desses deslizamentos." 

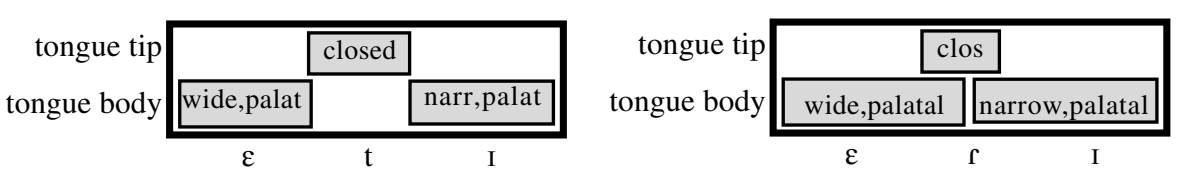

FIGURE 6 - Illustration of the flap in articulatory phonology (ALBANO, 2001)

With this overlapping process, gestural phonologies are able to explain various phenomena, such as:

- The aspiration of syllable-initial plosives, which, in fact, is a gradient phenomenon and, hence, does not fit in any (post-)generative phonology;

- Pre- and post-vocalic "l”, i.e. purely alveolar [1] and velar-alveolar [ł], respectively;

- The variation of word-final plosives [p, t, k, b, d, g] and the glottal stop [?];

- The apparent erasing of features, as [t] in 'perfect memory', or the schwa in 'beret';

- The apparent transformation of $[\mathrm{t}]$ into $[\mathrm{k}]$ in 'late class', or that of $[\mathrm{n}]$ into $[\mathrm{m}]$ in 'seven plus'.

The explanation to all those phenomena is done through two gradient modifications during speech: the increase of gestural overlap and the decrease of gestural magnitude. Differently from the rules and maneuvers of feature phonologies, gestures are never erased, they are never transformed into other gestures, and new gestures are never added. It is crucial to remember that this explanation is based on actual articulatory and acoustics data, collected and analyzed by means of electropalatography, electromyography, fibroscopy, transillumination, X-rays, etc. (for articulatory data); and spectral analyses (for acoustic data), and not by means of appropriateness judgments done by the researcher or other native speakers.

It is for those reasons that Albano concludes, in her review of articulatory phonology, that 
due to its elegant solutions for these problems, which are so difficult to tackle in post-generative phonologies, even in the non-linear models, the least that can be said about articulatory phonology is that it adequately models, in an initial appreciation, "linguistic phonetics" 6 (ALBANO, 2001, p. 59).

The main reason for Albano to say "in an initial appreciation" in her review is because of the emphasis that she gives to the acoustic role in the constitution of gestures. Albano (2001) proposes an Acoustic-Articulatory Phonology, which signals her affiliation to Browman and Goldstein's proposal, but also emphasizes "the importance of the articulatory-acoustic relations for measurement issues" (ALBANO 2001, p. 104). The importance of including the acoustic component in the model is somewhat related to Steven's Quantal Theory (STEVENS, 1972), previously discussed.

According to Albano, both the articulatory and the acoustic dimensions are involved in the gesture. To make her point, she mentions bite-block studies, in which participants use an apparatus that temporarily restricts the movement of their jaws in a certain way. As they are elicited to say something, they are able to adapt the trajectories of the articulators in order to produce the appropriate acoustic output. This way, it is possible to produce an [i] with a lowered jaw and an $[æ]$ without lowering the tongue. Therefore, for a more accurate investigation of the gesture, the articulatory production should not be overemphasized at the expense of the acoustic results.

\section{Revisiting and summarizing acquisition from a complexity perspective}

Finally, concerning language acquisition, Browman and Goldstein (1989a, 1992) refer to a series of studies that suggest that a child's first words are not stored and accessed as phonemes, but as "holistic patterns of articulatory routines" (BROWMAN; GOLDSTEIN, 1992, p. 39). The basic units of such articulatory routines are gestures that emerge pre-linguistically and that can be observed during

\footnotetext{
6 "diante da elegância das soluções obtidas para esses problemas, tão difíceis de tratar no quadro das fonologias pós-gerativas, mesmo não lineares, o mínimo que se pode dizer da fonologia articulatória é que ela modela adequadamente, em primeira aproximação, a 'fonética linguística'."

7 "a importância das relações acústico-articulatórias para a questão da comensurabilidade."
} 
babbling. The repetition of these microscopic elements, which takes us back to the iterative and fractal characteristics of complex systems, leads to the emergence of macroscopic phonic patterns. That is, the pre-linguistic units gradually develop into gestural units of contrast. During acquisition, the child distinguishes and adjusts his/her emerging gestures and, simultaneously, learns how to coordinate them, for it is not enough to be able to produce all the gestures of a word, the child needs to coordinate them.

Albano $(1990,2001)$ points out that the only thing that is innate is the capacity to associate auditory consequences to discrete constructions in the vocal tract. She also states that making constrictions in the vocal tract and associating them with acoustic consequences is learned with practice and experience. It is necessary to try and repeat in order to learn. In addition, Albano points out that there are several individual differences in relation to the ability to achieve the acquisition target, just as in any other sensory-motor activity of development, which explains the different rates of acquisition among children of the same age, or among L2 learners of the same age. This perspective in which articulatory productions need to be associated with acoustic consequences reinforces the need to include the acoustic dimension with the same degree of importance as the articulatory dimension in a gestural and dynamic phonological model, as proposed by Albano (2001).

Silva (2003, p. 329) appropriately summarizes the view of language acquisition on the grounds of articulatory phonology saying that "the symbolic (phonological) emerges from the repetition of gradient, numeric patterns (phonetic)" ${ }^{8}$ According to her, the greatest consequence of this relation between the symbolic and the gradient (or between the phonological and the phonetic) in articulatory phonology is that it discards the need for a set of derivational rules to link one level to the other. Once the gesture is at the same time a dynamic unit, defined by the single oscillatory system equation, and a symbolic unit, the bridge between the phonetic (physical, numeric, gradient, microscopic) and the phonological (cognitive, symbolic, discrete, macroscopic) dimensions comes in a natural, automatic, direct, and implementational manner.

As has been mentioned, this dynamic view of acquisition is aligned with other theories, such as the connectionist view of acquisition (e.g. ELMAN et al.,

\footnotetext{
8 "o simbólico (fonológico) emerge a partir da repetição de padrões gradientes, numéricos (fonéticos).”
} 
1996; ELMAN, 1998; GASSER, 1990; ELLIS, 2003; ALVES; ZIMMER, 2005; THELEN; BATES, 2003), which views language acquisition just like the acquisition of any other type of knowledge. Because it is a stochastic and probabilistic process, acquisition is put forward by the frequency of the structures present in the input, from which the child makes generalizations, tests hypotheses, and categorizes forms. Probabilistics also operates in the output, with the iterative processes of trial and error affecting the categorizations established by children in an acquisition phase.

Exemplar Theory (PIERREHUMBERT, 2001a, 2001b) is also aligned with the probabilistic and stochastic view of acquisition, which, in turn, is aligned with Probabilistic Linguistics (BOD; HAY; JANNEDY, 2003). In Exemplar Theory, the frequency in which tokens appear in the input and in the output has a paramount role in the organization of the linguistic system as a whole and, thus, in the phonological system as well. In this theory, the phonetic details (microscopic) are learned in association with lexical items. The same is true in Usage-Based Phonology (BYBEE, 2001, 2002a, 2002b, 2008,2010 ), yet with an extra focus on the experiences of language use. In this perspective, exemplars that are frequent and related to personal experiences, or that are recent, tend to be strengthened and fixed, whereas exemplars which are not very frequent, distant and/or not related to personal experience, tend to be weakened and even disappear.

This social aspect of language and language acquisition is what, according to Cirstófaro-Silva (2006a), creates a gap between connectionist models and her Multirepresentational Models. Cristófaro-Silva (e.g. 2003, 2005, 2006a, 2006b, 2007, CRISTÓFARO-SILVA; GOMES, 2007) uses the principles of probabilistic and usage-based phonologies to propose models of linguistic representation that are connected in networks in the various levels of grammar, with the lexical item as the locus of representation. The many phonetic possibilities of one lexical item are grouped in categories that exhibit prototypical effects. This lexical item is interconnected to others according to their relations in form and/or meaning. The social, stylistic, dialectal, pragmatic and genre-related relations also establish interconnections. Language use molds, modifies, strengthens or weakens relations. Therefore, the density of exemplars, and consequently, the emergence of phonological categories are defined probabilistically.

The result these models of acquisition have on SLA is that learners associate "sound patterns known in their mother tongue with sound patterns 
of the foreign language that are unknown"' (CRISTÓFARO SILVA, 2007, p. 79), which resembles Flege's Speech Learning Model (1995, 1999, 2007). Flege suggests that the necessary mechanisms for sound production remain intact throughout one's life. What happens is that, as we mature, it becomes more difficult to notice the sounds of an L2 which are too close to the sounds of our L1. Therefore, the sounds that contrast the least are the hardest to learn and master, since learners tend not to perceive them as different or distinct. As a result, because the adult $\mathrm{L} 2$ learners fail to notice a certain sound of the L2 as different from a close sound of their L1, they end up classifying the L2 sound under a (prototypical) phonological category of their L1. This way, "L2 pronunciation accuracy may decline, not because one has lost the ability to learn to pronounce, but because one has learned to pronounce the L1 so well" (FLEGE, 1999, p. 125).

Kuhl $(1991,1993)$ also talks about phonological prototypes that act as magnets to explain the phonological comprehension that people have of the phonetic variations of different speakers, regional or idiosyncratic variations. However, these prototypes of the L1 act on L2 learners as a Native Language Magnet, which prevents the learner from distinguishing L2 sounds from L1 sounds, because unknown L2 sounds will be attracted to the closest L1 prototype, which act as an attractor. As a consequence, in order to establish a network of exemplars in the L2, not only do learners need to construct new phonological categories for the new L2 sounds, but they also need to develop the ability to find phonetic consistency in the idiosyncratic variations in the production of different speakers in order to group those exemplars in the newly formed category (LEATHER, 2003).

Some examples of sound categories of English that are usually assigned to a single L1 category by Brazilian learners are:

- [ii] and [I], which tend to the assigned to the prototype of [i];

- $[\mathrm{u}:]$ and $[u]$, which tend to the assigned to the prototype of [u];

- $[\varepsilon]$ and $[x]$, which tend to the assigned to the prototype of $[\varepsilon]$;

- $[\theta]$, which tends to the assigned to the prototype of $[t],[s]$ or $[\mathrm{f}]$;

- [ð], which tends to the assigned to the prototype of [d], [z] or [v].

\footnotetext{
9 "padrōes sonoros conhecidos da língua materna com padrões sonoros desconhecidos da língua estrangeira."
} 
The aforementioned perspectives on language acquisition are, in different degrees, complementary and in keeping with a functional and dynamic approach to language acquisition, be it L1 or L2. In all of them, acquisition takes place without the need of an innate acquisition mechanism or a universal grammar, for linguistic patterns emerge from the frequent (iterative) and socially meaningful use of forms.

\section{Conclusion}

This paper aimed at situating phonological theory, representation and analyses in light of complex systems theory as has been applied to second language acquisition. The plethora of perspectives and approaches herein presented all have in common the view that language, as well as language acquisition, is a complex dynamic system, which has its own complex subsystems that operate iteratively so that the global patterns and behavior of the system may emerge. The phonetic and phonological dimensions of language (acquisition) research are examples of such complex subsystems and, therefore, should not be investigated in isolation.

As has been shown in this paper, complexity theory presents itself as a theoretical foundation that adequately encompasses the complex and dynamic nature of language and language acquisition. Therefore, the models of phonological representation and analyses, as well as those of SLA, reviewed in this paper, which are all based on complexity theory, are suitable for the current scientific context of language and SLA research.

\section{References}

ALBANO, E. C. Da fala à linguagem tocando de ouvido. São Paulo: Martins Fontes, 1990.

ALBANO, E. C. O gesto e suas bordas: esboço de fonologia acústico-articulatória do português brasileiro. Campinas: Mercado das Letras, 2001.

ALVES, U. K.; ZIMMER, M. C. Perceber, notar e aprender: uma visão conexionista da consciência do aprendiz na aquisição fonológica da L2. Revista Virtual de Estudos da Linguagem - ReVEL, v. 3, n. 5, p. 1-23, 2005.

BAK, P. How Nature Works: The Science of Self-Organized Criticality. New York: Copernicus, 1996.

BARBOSA, P. A. Incursöes em torno do ritmo da fala. Campinas: Pontes/Fapesp, 2006. 
BARBOSA, P. A. Prosódia. Enciclopédia Virtual de Psicolinguistica, 2008. Available at: <http://wikipsicolinguistica.org>. Retrieved August 182012.

BASSANO, D., VAN GEERT, P. Modeling continuity and discontinuity in utterance length: a quantitative approach to changes, transitions and intraindividual variability in early grammatical development. Developmental Science, v. 10, n. 5, p. 588-612, 2007.

BOD, R.; HAY, J.; JANNEDY, S. (Orgs) Probabilistic linguistics. Cambridge, MA: MIT Press, 2003.

BROWMAN, C. P.; GOLDSTEIN, L. Articulatory gestures as phonological units. Haskins Laboratories Status Report on Speech Research, SR-99/100, p. 69101, 1989a.

BROWMAN, C. P.; GOLDSTEIN, L. Articulatory Phonology - an overview. Haskins Laboratories Status Report on Speech Research, SR-111/112, p. 23-42, 1992.

BROWMAN, C. P.; GOLDSTEIN, L. Dynamics Articulatory Phonology. Haskins Laboratories Status Report on Speech Research, SR-113, p. 51-62, 1993.

BROWMAN, C. P.; GOLDSTEIN, L. Gestural specification using dynamicallydefined articulatory structures. Haskins Laboratories Status Report on Speech Research, SR-103/104, p. 95-110, 1990a.

BROWMAN, C. P.; GOLDSTEIN, L. Gestural structures and phonological patterns. Haskins Laboratories Status Report on Speech Research, SR-97/98, p. 123, $1989 \mathrm{~b}$.

BROWMAN, C. P.; GOLDSTEIN, L. Representation and reality: physical systems and phonological structure. Haskins Laboratories Status Report on Speech Research, SR-105/106, p. 83-92, 1990 b.

BROWMAN, C. P.; GOLDSTEIN, L. Some Notes on Syllable Structure in Articulatory Phonology. Haskins Laboratories Status Report on Speech Research, SR-93/94, p. 85-102, 1988.

BROWMAN, C. P.; GOLDSTEIN, L. Tiers in articulatory phonology, with some implications for casual speech. Haskins Laboratories Status Report on Speech Research, SR-92, p. 1-30, 1987.

BYBEE, J. Language, usage and cognition. Cambridge: Cambridge University Press, 2010.

BYBEE, J. Phonological evidence for exemplar storage of multiword sequences. Studies in Second Language Acquisition, v. 24, p. 215-221, $2002 \mathrm{a}$.

BYBEE, J. Phonology and Language Use. Cambridge: Cambridge University Press, 2001. 
BYBEE, J. Usage-based grammar and second language acquisition. In: ROBINSON, P.; ELLIS, N. Handbook of Cognitive Linguistics and Second Language Acquisition. New York: Routledge, 2008. p. 216-236.

BYBEE, J. Word frequency and context of use in the lexical diffusion of phonetically conditioned sound change. Language Variation and Change, v. 14, p. 261-290, 2002b.

CAMERON, L. Metaphor in Educational Discourse. London: Continuum, 2003. CHOMSKY, N.; HALLE, M. The sound pattern of English. New York, Evanston e Londres: Harper and Row, Publishers, 1968.

COOPER, D. Linguistic Attractors: The cognitive dynamics of language acquisition and change. Amsterdam; Philadelphia: John Benjamins, 1999.

COUTO, H. H. Ecolingüistica: estudo das relações entre língua e meio ambiente. Brasília: Thesaurus Editora, 2007.

CRISTÓFARO-SILVA, T. Descartando fonemas: a representação mental da fonologia de uso. In: HORA, D.; COLLISCHONN, G. Teoria linguistica: fonologia e outros temas. João Pessoa: Editora Universitária, 2003.

CRISTÓFARO-SILVA, T. Fonética e fonologia: perspectivas complementares. Estudos das Lingua(gem), v. 3, p. 25-40, 2006 b.

CRISTÓFARO-SILVA, T. Fonologia probabilística: estudos de caso do português brasileiro. Lingua (gem), v. 2, n. 2, p. 223-248, 2005.

CRISTÓFARO-SILVA, T. Modelos multirrepresentacionais em fonologia. In: MARCHEZAN, R. C.; CORTINA, A. (Orgs). Os fatos da linguagem, esse conjunto heteróclito. Araraquara: Laboratório Editorial da FCL, 2006a. p. 171-185.

CRISTÓFARO-SILVA, T. O Ensino de Pronúncia na Aula de Língua Estrangeira. In: FONSECA-SILVA, M. C.; PACHECO, V.; LESSA-DEOLIVEIRA, A. S. C. Em torno da lingua(gem): questóes e análises. Vitória da Conquista: Edições UESB, 2007.

CRISTÓFARO-SILVA, T.; GOMES, C. A. Aquisição fonológica na perspectiva multirrepresentacional. Letras de Hoje, v. 42, n. 1, p. 179-191, 2007.

DE BOT, K. Introduction: second language development as a dynamic process. The Modern Language Journal, v. 92, n. 2, p. 166-179, 2008.

DE BOT, K.; LOWIE, W.; VERSPOOR, M. A Dynamic Systems Theory approach to second language acquisition. Bilingualism: Language and Cognition, v. 10, n. 1, p. 7-21, 2007.

ELLIS, N. Constructions, chunking and connectionism. In: DOUGHTY, C. J.; LONG, M. H. (Orgs.). The handbook of second language acquisition. Oxford, Massachusetts and Victoria: Blackwell Publishing, 2003. Cap. 4, p. 63-103. 
ELLIS, N. Emergentism, connectionism and language learning, Language Learning, v. 48, n. 4, p. 631-664, 1998.

ELLIS, N. The dynamics of second language emergence: cycles of language use, language change, and language acquisition. The Modern Language Journal, v. 92, n. 2, p. 232-249, 2008b.

ELLIS, N. Usage-based and form-focused language acquisition: the associative learning of constructions, learned attention, and the limited L2 endstate. In: ROBINSON, P.; ELLIS, N. Handbook of cognitive linguistics and second language acquisition. New York: Routledge, 2008a. p. 372-405.

ELLIS, N.; LARSEN-FREEMAN, D. Constructing a second language: analyses and computational simulations of the emergence of linguistic constructions from usage. Language Learning, v. 59, suppl. 1, p. 90-125, 2009.

ELLIS, N.; LARSEN-FREEMAN, D. Language emergence: implications for applied linguistics—introduction to the special issue. Applied Linguistics, v. 27, n. 4, p. 558-589, 2006.

ELMAN, J. L. Connectionism, artificial life, and dynamical systems: new approaches to old questions. In: BECHTEL, W.; GRAHAM, G. (Orgs.). A Companion to Cognitive Science. Oxford: Basil Blackwood, 1998.

ELMAN, J. L. Language as a dynamical system. In: PORT, R.; VAN GELDER,T. Mind as Motion: explorations in the dynamics of cognition. Cambridge, MA: MIT Press, 1995. p. 195-223.

ELMAN, J. L.; BATES, E. A.; JOHNSON, M. H. KARMILOFF-SMITH, A.; PARISI, D.; PLUNKETT, K. Rethinking innateness: a connectionist perspective on development. Cambridge, MA: The MIT Press, 1996.

FLEGE, J. Age of learning and second language speech. In: BIRDSONG, D. (Org.) Second language acquisition and the Critical Period Hypothesis. Mahwah: Lawrence Erlbaum Associates, 1999. p. 101-131.

FLEGE, J. Language contact in bilingualism: phonetic systems interaction. In: COLE, J.; HUALDE, J. I. (Orgs.) Laboratory phonology 9. Berlim: Mouton de Gruyter, 2007. Cap. 16, p. 353-382.

FLEGE, J. Second language speech learning theory, findings, and problems. In: STRANGE, W. (Org.) Speech perception and linguistic experience: issues in crosslanguage research. Baltimore: York Press, 1995. p. 233-277.

FLEGE, J. The development of early L2 phonology: a dynamic approach. In: INTERNATIONAL SYMPOSIUM ON THE ACQUISITION OF SECOND LANGUAGE SPEECH NEW SOUNDS, 6, 2010, Poznán, Poland. New Sounds 2010 Proceedings, 2010. Available at: <http://ifa.amu.edu.pl/newsounds/ Proceedings_guidelines>. Retrieved August 182012. 
GASSER, M. Connectionism and universals of second language acquisition. Studies in Second Language Acquisition, v. 12, n. 2, p. 179-199, 1990.

GOLDSMITH, J. A. Autosegmental and metric phonology. Oxford; Cambridge: Basil Blackwell, 1990.

HALLIDAY, M. A. K. Introduction to Functional Grammar. Londres: Edward Arnold, 1994.

HERDINA, P.; JESSNER, U. A dynamic model of multilingualism: perspective of change in psycholinguistics. Clevedon: Multilingual Matters, 2002.

JESSNER, U. A DST model of multilingualism and the role of metalinguistic awareness, The Modern Language Journal, v. 92, n. 2, p. 270-283, 2008.

JOHNSON, K. Acoustics and auditory phonetics. Malden, MA: Blackwell Publishing, 1997.

KEATING, P. The phonetics-phonology interface. In: NEWMEYER, F. (Org.) Linguistics: The Cambridge survey, v. 1. Cambridge, MA: Cambridge University Press, 1989. p. 281-302.

KUHL, P. K. Human adults and human infants show a "perceptual magnet effect" for prototypes of speech categories, monkeys do not. Perception \& Psychophysics, v. 50, p. 93-107, 1991.

KUHL, P. K. Innate predispositions and the effects of experience in speech perception: the native language magnet theory. In: BOYSSON-BARDIES, B. (Org.) Developmental neurocognition: speech and face processing in the first year of life. The Hague: Kluwer Academic Publishers, 1993. p. 259-74.

LARSEN-FREEMAN, D. Chaos/complexity science and second language acquisition. Applied Linguistics, v. 18, n. 2, p. 141-165, 1997.

LARSEN-FREEMAN, D. On the complementarity of Chaos/Complexity Theory and Dynamic Systems Theory in understanding the second language acquisition process. Bilingualism: Language and Cognition, v. 10, n. 1, p. 35-37, 2007.

LARSEN-FREEMAN, D.; CAMERON, L. Complex systems and applied linguistics. Oxford: Oxford University Press, 2008a.

LARSEN-FREEMAN, D.; CAMERON, L. Research Methodology on Language Development from a Complex Systems Perspective. The Modern Language Journal, v. 92, n. 2, p. 200-213, 2008b.

LEATHER, J. (Org.) Phonological issues in language learning. Malden; Oxford: Blackwell Publishers, 1999. 
LEATHER, J. Phonological acquisition in multilingualism. In: GARCÍA MAYO, M. P.; GARCÍA LECUMBERRI, M. L. Age and the acquisition of English as a foreign language. Clevedon; Tonawanda; New York; Ontario: Multilingual Matters Ltd, 2003. Cap. 2, p. 23-58.

LEATHER, J.; VAN DAM, J. (Orgs.) Ecology of Language Acquisition. Dordrecht: Kluwer Academic Publishers, 2003.

LORENZ, E. Predictability: Does the flap of a butterfly's wing in Brazil set off a tornado in Texas? Paper presented at the annual meeting of the American Association for the Advancement of Science, Washington, DC., 1972.

LOWIE, W. The development of early L2 phonology: a dynamic approach. In: INTERNATIONAL SYMPOSIUM ON THE ACQUISITION OF SECOND LANGUAGE SPEECH NEW SOUNDS, 6, 2010, Poznán, Poland. New Sounds 2010 Proceedings, 2010. Available at: <http://ifa.amu.edu.pl/newsounds/ Proceedings_guidelines>. Retrieved August 182012.

MACWHINNEY, B. (Org.) The Emergence of Language. Mahwah, NJ: Lawrence Erlbaum Associates, 1999.

MACWHINNEY, B. Emergentism - use often and with care. Applied Linguistics, v. 24, n. 4, p. 729-740, 2006.

MACWHINNEY, B. Models of emergence of language. Annual Review of Psychology, v. 49, p. 199-227, 1998.

MACWHINNEY, B. The emergence of linguistic form in time. Connection Science, v. 17, p. 119-211, 2005

PENnington, M. C. (Org.) Phonology in Context. New York: Palgrave Macmillan, 2007.

PIERREHUMBERT, J. B. Exemplar dynamics: word frequency, lenition and contrast. In: BYBEE, J.; HOOPER, P. (Orgs) Frequency and the Emergency of Linguistic Structure. Amsterdam: J. Benjamins, 2001b. p. 137-157.

PIERREHUMBERT, J. B. Phonetic diversity, statistical learning, and acquisition of phonology. Language and Speech, v. 46, n. 2-3, p. 115-154, 2003. PIERREHUMBERT, J. B. Phonological and phonetic representation. Journal of Phonetics, v. 18, p. 375-394, 1990.

PIERREHUMBERT, J. B. Stochastic phonology. Glot International, v. 5, n. 6, p. 195-207, 2001a.

PIERREHUMBERT, J. B. What people know about sounds of language. Studies in the Linguistic Sciences, v. 29, n. 2, p. 111-120, 1999.

PIERREHUMBERT, J.B. Word-specific phonetics. Laboratory Phonology VII, Mouton de Gruyter, Berlin, p. 101-139, 2002. 
PORT, R. The Dynamical Systems Hypothesis in Cognitive Science. In: NADEL, L. Encyclopedia of Cognitive Science. London: Macmillan, 2002. p. 1027-1032.

PORT, R.; VAN GELDER, T. Mind as motion: exploration in the dynamics of cognition. Cambridge, MA: Bradford, 1995.

SALTZMAN, E. Task dynamic coordination of the speech articulators: a preliminary model. In: HEUER, H.; FROMM, C. (Orgs.) Generation and Modulation of Action Patterns. Berlin: Springer-Verlag, 1986. p. 129-144.

SELINKER, L. Interlanguage. International Review of Applied Linguistics, v. 10, n. 3, p. 209-231, 1972.

SILVA, A. H. P. Pela incorporação de informação fonética aos modelos fonológicos. Revista Letras, n. 60, p. 319-333, 2003.

SILVA, A. H. P. Towards a Dynamic View on L2 Phonological Acquisition. In: INTERNATIONAL SYMPOSIUM ON THE ACQUISITION OF SECOND LANGUAGE SPEECH NEW SOUNDS, 5, 2007, Florianópolis, Brasil. RAUBER, A. S.; WATKINS, M. A.; BAPTISTA, B. O. (Orgs.). New Sounds 2007: Proceedings of the Fifth International Symposium on the Acquisition of Second Language Speech, 2008. p. 448-458. Available at: <http://www.nupffale.ufsc.br/ newsounds/proceedings.htm>. Retrieved August 182012.

STEVENS, K. N. The quantal nature of speech: evidence from articulatory-acoustic data. In: DAVID JR, E. E.; DENES, P. B. (Orgs.) Human Communication: a unified view. New York: McGraw-Hill, 1972. p. 51-66.

THELEN, E.; BATES, E. Connectionism and dynamic systems: are they really different? Developmental Science, v. 6, n. 4, p. 378-391, 2003.

THELEN, E.; SMITH, L. A Dynamic Systems Approach to the Development of Cognition and Action. Cambridge, MA: The MIT Press, 1994.

VAN LIER, L. The Ecology and Semiotics of Language Learning: a Sociocultural perspective. Boston: Kluwer Academic Publishing, 2004.

VERSPOOR, M.; DE BOT, K.; LOWIE, W. (Orgs.) A Dynamic Approach to Second Language Development: Methods and Techniques. Amsterdam; Philadelphia: John Benjamins, 2011.

VERSPOOR, M.; LOWIE, W.; VAN DIJK, M. Variability in second language development from a dynamic systems perspective. The Modern Language Journal, v. 92, n. 2, p. 214-231, 2008.

Recebido em 28/08/2012. Aprovado em 08/01/2013. 